\title{
Grzegorz Rossoliński-Liebe, Bandera. Życie i mit ukraińskiego nacjonalisty: faszyzm, ludobójstwo, kult, Wydawnictwo Pruszyński i S-ka, Warszawa 2018, SS. 904
}

$\mathrm{H}$ egemonia ruchu OUN-B [banderowszczyzna - I. I.] desakralizuje ukraińską ideę narodową. Co jest warta ta idea, jeśli »wolni« Ukraińcy nie potrafią sprzeciwić się bolszewizmowi niczym lepszym, jak tylko bardziej prymitywnym wytworem samego bolszewizmu? Wyznaję opinię, że nasi domorośli totalitaryści nie różnią się w kategoriach moralności od bolszewików, są tylko od nich mniej inteligentni"'.

Chociaż badania naukowe dotyczące prezentowanej problematyki mają swoją historię, do czasu powstania niniejszego opracowania nie napisano wszechstronnej naukowej biografii Stepana Bandery ani studium jego kultu. Autor koncentruje się na życiu politycznym i kulcie Bandery, rekonstruuje jego światopogląd na podstawie książek i gazet, które ten czytał, publikował albo redagował, opinie, które żywił i które publicznie głosił, licznych dokumentów archiwalnych, wspomnień spisanych przez osoby, które go znały, jak również na podstawie działalności bojowej i propagandowej, którą organizował i w której uczestniczył. Znaczną część książki zajmuje historia Organizacji Ukraińskich Nacjonalistów (OUN) i Ukraiń-

\footnotetext{
${ }^{1}$ Iwan Łysiak-Rudnicki do Iwana Kedryna-Rudnyćkiego, 26 kwietnia 1974, Archives of the Shevchenko Scientific Society in New York, zbiór Iwana Kedryna-Rudnyćkiego, 4, k. 23-24, [w:] G. Rossoliński-Liebe, Bandera. Życie i mit ukraińskiego nacjonalisty: faszyzm, ludobójstwo, kult, Warszawa 2018, s. 676-677.
} 
skiej Powstańczej Armii (UPA), by zapewnić wiedzę o latach życia i działalności ideologa tych organizacji.

Analizując te źródła, autor pokazuje, że poglądy bohatera, jego opowieści, ukształtowane zostały przez ideologię licznych ukraińskich i zagranicznych myślicieli faszystowskich i skrajnie prawicowych. Światopogląd Bandery ukształtowany zatem został przez zbiór skrajnie prawicowych wartości, takich jak ultranacjonalizm, faszyzm, rasizm i antysemityzm, a także przez fascynację przemocą, wiarę, że tylko wojna może doprowadzić do stworzenia państwa ukraińskiego, oraz przez wrogość do demokracji. Jak inni ukraińscy nacjonaliści, łączył ekstremizm z religią i wykorzystywał ją do sakralizacji polityki i przemocy.

Forma książki zdeterminowana jest przez zainteresowania badawcze, długi okres objęty narracją i zastosowane metody. Autor wpisuje Banderę i kierowany przez niego ruch w kontekst innych ruchów faszystowskich w Europie Środkowo-Wschodniej, naświetla i uściśla definicję faszyzmu, wyjaśnia różnice między faszyzmem i nacjonalizmem - dwoma dość mocno związanymi zjawiskami. Zdaniem autora ruch Bandery czy OUN spełnia główne kryteria zawarte w istniejących i przeanalizowanych prze niego koncepcjach faszyzmu. Przy tym Rossoliński-Liebe nie nalega na używanie terminu ,faszyzm”. W swoim studium zatem nazywa ten ruch albo nacjonalistycznym, albo faszystowskim, w zależności od kontekstu. Pisze, że głównymi celami ruchu było zwalczanie i usunięcie „okupantów” z terytoriów ukraińskich oraz ustanowienie niezależnego państwa ukraińskiego. Autor uważa, że ten ruch jest formą faszyzmu narodu bez państwa. Według niego w tym sensie OUN była blisko związana z takimi ruchami jak chorwackie ustasze (Hrvatska revolucionarna organizacija, HRO) i partia Hlinki (Hlinkowa slovenská l’udová strana, HSLS), które również były zakorzenione w społeczeństwach pozbawionych państw narodowych.

$\mathrm{W}$ podsumowaniu do rozdziału 1 autor sformułował te zagadnienia w następujący sposób: „Choć OUN kładła nacisk na swój nacjonalistyczny, patriotyczny i romantyczny charakter, była typowym wschodnioeuropejskim ruchem faszystowskim. Orientując się na nazistowskie Niemcy i współpracując z Włochami Mussoliniego oraz chorwackimi ustaszami, próbowała przejąć władzę na Ukrainie i stworzyć państwo typu faszystowskiego" (s. 139). W innym miejscu Rossoliński-Liebe udowadnia, że poza nacjonalizmem i faszyzmem ważnymi koncepcjami ideologicznymi ruchu Bandery były rasizm i eugenika. Według niego: „W ukraińskim nacjonalizmie segregacja rasowa i eugenika pojawiły się w kontekście oczyszczenia na- 
rodu, kultury i języka ukraińskiego z obcych - w szczególności polskich, rosyjskich i żydowskich - wpływów w celu uzyskania czystej »rasy « ukraińskiej”. Podkreśla, ,że tego rodzaju pogląd był typowy dla radykalnych ruchów prawicowych zakorzenionych $\mathrm{w}$ narodach, które przez stulecia były prowincjami imperiów albo pozostawały pod istotnym wpływem innych kultur" (s. 173).

Podobny punkt widzenia na ukraiński nacjonalizm jak na formę faszyzmu był wcześniej w historiografii omawiany w publikacjach Franka Golczewskiego, Marco Carynnyka, Martina Terry'ego, Per Andersa Rudlinga, Antona Szechowcowa, Timothy'ego Snydera, Ołeksandra Zajcewa, Georgija Kasjanowa i in. Przyznaje to sam autor. Przy tym według niego krytyka ukraińskiego nacjonalizmu, dokonana np. przez Snydera, nie odpowiada bardziej apologetycznej postawie tego badacza wobec polskiej historii (s. 775). Autor również wskazuje, że w opracowaniach Dietera Pohla, Grzegorza Motyki „rola OUN i UPA w Holokauście jest niedostatecznie uwzględniona” albo nawet „tylko marginalnie zbadana” (s. 67-68).

Moim zdaniem od poprzednich badaczy różni autora przede wszystkim większa liczba szczegółów dotyczących ideologii OUN i postaci Bandery, również użycie mocniejszych politycznych lub ideologicznych określeń pod adresem ostatnich. To chyba też pierwsze takie dogłębne studium kultu tej postaci. Przy tym Rossoliński-Liebe zwraca szczególną uwagę na wyjaśnienie wpływu radzieckiej ideologii i propagandy na obraz Bandery w czasie zimnej wojny i po rozpadzie Związku Radzieckiego. Według niego, w przeciwieństwie do zbrodni nacjonalistów, zbrodnie radzieckie były całkowicie nieobecne w oficjalnym dyskursie pamięci. W reakcji na to zachodni Ukraińcy stworzyli nieformalny antyradziecki buntowniczy dyskurs dotyczący OUN i UPA. Dyskurs ten przekształcił te organizacje w symbol oporu. Z biegiem czasu ,kryminalna, autorytarna i głęboko antydemokratyczna natura ukraińskiego ruchu nacjonalistycznego została pogrzebana w zapomnieniu, a ukraińscy nacjonaliści pojawili się ponownie, zwłaszcza pod koniec lat osiemdziesiątych, jako antyradzieccy bojownicy o wolność" (s. 599). W rozumieniu autora ,postradziecka polityka pamięci na Ukrainie całkowicie zignorowała demokratyczne wartości i nie stworzyła żadnego rodzaju nieapologetycznego podejścia do historii” (s. 825), a „nowymi wrogami banderowców stali się mówiący po rosyjsku wschodni Ukraińcy, Rosjanie i demokraci, których chcieliby ukrainizować albo zbanderyzować" (s. 826-827). 
Badania nad życiem Bandery, jego kultem i historią OUN i UPA autor w znacznej mierze stara się oprzeć na licznych materiałach archiwalnych (przede wszystkim niemieckich, polskich, ukraińskich, rosyjskich, ale także archiwalnych zbiorach amerykańskich, kanadyjskich i brytyjskich). Wykorzystuje również oryginalne publikacje, które wywarły znaczny wpływ na ideologię, polityczno-strategiczne cele i wojenną doktrynę OUN i UPA (pisma i prace Mykoły Michnowśkiego, Dmytra Doncowa, Mykoły Sciborśkiego, Stepana Rudnyćkiego, Mychajła Kołodzińskiego, Wołodymyra Martyncia, Jewhena Onaćkiego, Jarosława Orszana, a także główne czasopisma OUN „Surma”, „Rozbudowa Nacji” i in.). Autor omawia niektóre z wykorzystanych w pracy zbiorów archiwalnych (w całości kwerenda była przeprowadzona w ponad 30 zasobach archiwalnych i bibliotekach), jak również ich lokalizację, ale bardzo krótko. Czego może dowiedzieć się nowy czytelnik np. z tak ogólnikowej autorskiej wypowiedzi: „Ważne dokumenty dotyczące Bandery, OUN-UPA i niemieckiej okupacji Ukrainy znajdują się w Niemieckim Archiwum Federalnym (Bundesarchiv, BA) w Berlinie i Koblencji, w Archiwum Wojskowym (Militärarchiv, MA) we Freiburgu i w Archiwum Politycznym Ministerstwa Spraw Zagranicznych (Politisches Archiv des Auswärtigen Amtes, PAAA) w Berlinie" (s. 63)? Niewiele. Nie ma tu żadnej informacji o tym, czym różni się treść zbiorów dokumentów zawartych w tych archiwach, ani o tym, jakie materiały i dla zbadania jakich aspektów prezentowanej problematyki były przez autora przestudiowane. Nawet w wypadku wykorzystanego w szerokim zakresie w książce ogromnego zbioru świadectw ocalałych Żydów, zebranych przez Archiwum Żydowskiego Instytutu Historycznego w Warszawie (AŻIH), Centralną Żydowską Komisję Historyczną (CŻKH), archiwum Holocaust Memorial Museum w Waszyngtonie i archiwum Yad Vashem, autor nie wyjaśnia, na czym polegają różnice i podobieństwa między nimi. Moim zdaniem, warto było rozszerzyć omówienie wykorzystanych w pracy materiałów archiwalnych, szczególnie w zakresie wyjaśnienia ich treści, metodologii i interpretacji. Autorskie uwagi odnośnie do wykorzystywania dwóch rodzajów dokumentów (pozostawionych przez sprawców oraz pozostawionych przez ofiary i ocalałych) uważam za niewystarczające. Tym bardziej że zamieszczono je w innym rozdziale, który nie dotyczy bazy źródłowej.

Autor natomiast wiele uwagi poświęcił manipulacjom dokumentami, zwłaszcza przedrukowanymi materiałami archiwalnymi, które w ostatnich latach ukazały się na Ukrainie. Jego zdaniem baza dokumentalna obejmu- 
je wiele ważnych materiałów i nie powinno się ich wykluczać wyłącznie dlatego, że ich autorzy zaprzeczają, że OUN i UPA stosowały przemoc etniczną i polityczną. Według autora po rozpadzie Związku Radzieckiego apologetyczna i wybiórcza narracja, zainicjowana przez ukraińskich historyków i innych autorów emigracyjnych, została przejęta przez większość patriotycznie nastawionych naukowców i działaczy mieszkających przede wszystkim w zachodniej Ukrainie, ale nie tylko. Jego zdaniem z jednej strony prace takich historyków zawierają ważne materiały, np. do biografii Bandery. Z drugiej strony propagują one kult prowidnyka i dlatego autor analizuje je oddzielnie w dwóch ostatnich rozdziałach książki, w których właśnie prezentuje kult Bandery.

W rozdziale zatytułowanym „Literatura” autor krótko omawia dotychczasowe opracowania przedmiotu, opublikowane po niemiecku, angielsku, polsku, rosyjsku, ukraińsku i wykorzystane w swojej pracy. Dotyczą one takich tematów, jak złożoność okresu międzywojennego i stosunków między Żydami, Polakami i Ukraińcami w II Rzeczypospolitej oraz sytuacja polityczna Ukraińców, stosunki niemiecko-ukraińskie w latach 1914-1939, historia nacjonalizmu ukraińskiego w XIX-na początku XX w., OUN i UPA, II wojna światowa i Holokaust, OUN w czasie zimnej wojny i in. Uważam jednak, że nie wszystkie najistotniejsze pozycje naukowe dotyczące tematu zostały uwzględnione i wskazane. Autor ignoruje cześć dorobku historiografii ukraińskiej na temat OUN i UPA i nawet w celu dyskusji nie wspomina o głównym osiągnięciu zespołu historyków i archiwistów przy Rządowej Komisji ds. Działalności Organizacji Ukraińskich Nacjonalistów i Ukraińskiej Powstańczej Armii (chociaż wzmiankuje o jej istnieniu), na czele z zastępcą dyrektora Instytutu Historii Ukrainy Narodowej Akademii Nauk Ukrainy prof. Stanisławem Kulczyckim. Chodzi o dzieła: Orhanizacija ukrajinśkych nacionalistiw i Ukrajinśka powstanśka armija. Istoryczni narysy, red. S. Kulczyćkyj, Kyjiw 2005²; Orhanizacija ukrajinśkych nacjonalistiw i Ukrajinśka powstanśka armija. Fachowyj wysnowok roboczoji hrupy istorykiw pry uriadowij komisiji z wywczennia dijalnosti OUN i UPA, red. S. Kulczyćkyj, Kyjiw $2005^{3}$.

\footnotetext{
2 Організація українських наиіоналістів і Українська повстанська армія. Історичні нариси, ред. С. Кульчицький, Київ 2005.

3 Організація украӥнських націоналістів і Українська повстанська армія. Фаховий висновок робочої групи істориків при урядовій комісії з вивчення діяльності ОУН ред. С. Кульчицький, Київ 2005.
} 
Chociaż w ostatnich dwóch dekadach powstało wiele ważnych prac dotyczących zagadnień podjętych w książce, autor przedstawił aktualny stan wiedzy w zakresie prezentowanej problematyki. Natomiast książkę napisał w sposób krytyczny wobec wielu poprzednich dzieł dotyczących zbliżonej tematyki. Podkreślił, że zrobił to „pod prąd” w celu ,ujawnienia kilku ukrytych, zapomnianych, ignorowanych albo zaciemnionych aspektów historii Ukrainy i innych historii narodowych" (s. 72). Według autora właśnie tym przede wszystkim różni się jego opracowanie od dotychczasowych studiów, które rozważają i zalety, i wady nacjonalizmu w życiu narodu albo eksplorują krótkotrwałe procesy, takie jak kolaboracja w konkretnym regionie albo kraju w czasie II wojny światowej, albo które niedostatecznie uwzględniają rolę OUN, UPA i lokalnej ludności w Holokauście.

Po przeczytaniu książki staje się jasne, że autorowi chodziło główne o nakreślenie sprawy zaangażowania OUN w Holokaust i że - jego zdaniem Bandera był odpowiedzialny za masową przemoc etniczną i polityczną, dlatego ponosi za to moralną, etyczną i polityczną odpowiedzialność, a nawet prawną: ,gdyby ukraiński sąd byłby zainteresowany, to skazałby jego i kilka innych przywódców OUN-B, zaangażowanych w przygotowanie i przeprowadzenie »Ukraińskiej Rewolucji Narodowej«” (s. 363). Przy czym autor zgadza się z tym, że „choć jego [Bandery] odpowiedzialność z pewnością różni się od odpowiedzialności Hitlera, Pavelicia czy Antonescu i innych przywódców, których ruchy popełniały zbrodnie wojenne albo były zaangażowane w okrucieństwa” (s. 362). Różnica ta, według autora, polega na tym, że „Bandera był istotnie jedynie »bierną postacią «” i ,po 22 czerwca 1941 r. nie wydawał bezpośrednich rozkazów" (s. 362).

Autor też potwierdza, że nie udało mu się ostatecznie ustalić, czy Bandera wydawał bezpośrednie rozkazy po 22 czerwca 1941 r., czy też nie (s. 361). Może przeszkodziła temu okoliczność, że Federalna Służba Wywiadowcza Niemiec (Bundesnachrichtendienst, BND) nie udostępniła autorowi większości istotnych dokumentów dotyczących współpracy służby bezpieczeństwa III Rzeszy z OUN, o czym pisze sam autor (s. 64)? Tego nie wiem. Jestem jednak pewien, że autor nie rozwiązał głównego postawionego sobie zadania, czyli nie zdołał wyjaśnić ,zniuansowaną, kompleksową i adekwatną" (s. 360) rolę, jaką odegrał podczas wojny Bandera, i dlatego wiele istotnych aspektów prezentowanej problematyki wciąż pozostaje niewyjaśnionych.

Recenzent nie chciałby być podobny do wielu innych osób, które główne braki i wady prac Grzegorza Rossolińskiego-Liebe upatrują w zastoso- 
wanej przez niego „błędnej metodologii” albo twierdzą, że te prace nie są „wystarczająco naukowe”, chociaż rzeczywiście życzyłbym sobie, żeby miały bardziej akademicki charakter. Nie uważam również autora za osobę, która ma ,złe intencje” wobec Ukrainy i Ukraińców, chociaż jak już wyżej powiedziałem, faktem jest, że nie docenia on dorobku historiografii ukraińskiej na temat OUN i UPA. Może ma rację? Ze względu na to, że nawet instytucje naukowe, np. Centrum Badań Ruchu Wyzwoleńczego we Lwowie ${ }^{4}$, stworzyły akademickie podstawy kultu Bandery i wybielania ukraińskiej historii z okrucieństw popełnionych przez OUN, a sam proces heroizacji ruchu Bandery, już po wydaniu książki Rossolińskiego, doprowadził do uchwalenia przez Radę Najwyższą Ukrainy dnia 9 kwietnia 2015 r. ustawy „O prawnym statusie i uczczeniu pamięci bojowników o niepodległość Ukrainy w XX wieku”, gloryfikującej OUN i UPA właśnie jako bojowników o niepodległość Ukrainy. Zdaniem autora na Ukrainie doszło „nie tylko do wybielania nacjonalistycznego ruchu z okrucieństw, ale też dokonano sakralizacji sprawców" (s. 833), a nieliczne krytyczne badania nad ukraińskim nacjonalizmem traktowano z podejrzliwością, niechęcią albo wrogością. Były one postrzegane ,jako skierowane przeciwko swojemu narodowi" (s. 827). Niestety, poza uwagą autora pozostało zagadnienie, jak polityka sąsiednich państw i sytuacja polityczna w Europie przyczyniły się do zradykalizowania nacjonalizmu w dzisiejszej Ukrainie.

Ale sens moich rozważań polega właśnie na tym, by pokazać, że autor, w odróżnieniu od przyjętego w historiografii ukraińskiej i polskiej poglądu, nie uważa ruchu Bandery za narodowo-wyzwoleńczy (s. 805). Grzegorz Rossoliński-Liebe twierdzi, że jego członkowie ,nie byli bohaterami, tylko sprawcami, którzy naruszyli kulturowe założenia swojej własnej tożsamości” (s. 834), wątpi też w to, że Armia Krajowa walczyła o niepodległość swojego narodu (s. 828). Przyjmując wiele z uwag autora na temat ideologii i praktyki ukraińskiego nacjonalizmu zawartych w jego książce, trudno jednak zgodzić się z jego głównym wnioskiem o charakterze ukraińskiego ruchu nacjonalistycznego. I nie chodzi tu nawet o jakiekolwiek własne poglądy i osobiste upodobania, a o to, jak ten ruch postrzegają zachodni Ukraińcy. Przecież traktują oni ideologię ukraińskiego nacjonalizmu jako część swojej tożsamości i kultury. Chyba mają do tego prawo. Sam autor

\footnotetext{
${ }^{4} \mathrm{Ukr}$ ЦЦентр досліджень визвольного руху.

5 Закон України Про правовий статус та вщанування пам'яті бориів за незалежність України у ХХ столітті, „Відомості Верховної Ради” (ВВР) 2015, № 25, ст.190.
} 
uważa, że ,antysemityzm i nacjonalizm głęboko zakorzenione są w ukraińskiej kulturze akademickiej i politycznej” (s. 831). Natomiast niewątpliwie Grzegorz Rossoliński-Liebe też ma prawo do własnego spojrzenia na charakter tego ruchu, podobnie jak wiele innych osób na Ukrainie i poza jej granicami, dla których Bandera nigdy nie był i nie będzie bohaterem i które zawsze będą przeciwdziałały próbom promowania nacjonalizmu i wzmacniania nacjonalistycznej wersji tożsamości ukraińskiej.

Badania nad biografią Bandery nie są zajęciem łatwym z uwagi na to, że jego mit polityczny jest utrwalony na różne sposoby, które zniekształciły i utrudnily postrzeganie oraz rozumienie jego osoby. Opracowania, które po 1990 r. ukazały się w Polsce, Rosji i na Ukrainie, choć zawierają wiele istotnych informacji na temat postaci Bandery i powiązanej z nią historii OUN i UPA, znacznie się różnią. Z jednej strony autorzy przedstawiają Banderę jako bohatera narodowego i ignorują albo zaprzeczają jego radykalnemu światopoglądowi i stosowaniu przez jego zwolenników przemocy etnicznej i politycznej. $Z$ drugiej strony niektórzy z nich pomijają milczeniem czynniki ekonomiczne, społeczne i polityczne, które przyczyniły się do powstania ukraińskiego ruchu radykalno-nacjonalistycznego i jego zaangażowania w czystki etniczne przeciwko ludności polskiej i inne formy przemocy etnicznej oraz politycznej, a nawet zaprzeczają zbrodniom wojennym popełnionym na ukraińskiej ludności cywilnej przez Niemców, Rosjan i Polaków.

Autor nie jest pierwszym historykiem, który próbuje zrozumieć rolę, jaką odegrał w XX-wiecznej historii Ukrainy Bandera, i usiłuje znaleźć odpowiedź na trudne pytania dotyczące jego życiorysu, takie jak: czy i w jakim stopniu był on odpowiedzialny za okrucieństwa popełniane przez OUN i UPA, w które nie był osobiście zaangażowany, ale które aprobował i które dokonane zostały przez ludzi utożsamiających się z jego osobą i poglądami? Zaznaczyć trzeba, że z tytułu książki można już jednak wnioskować, w jakim kierunku podążają autorskie odpowiedzi na te trudne pytania.

W zależności od kontekstu autor omawianego dzieła używa takich terminów jak ,masowa przemoc”, ,,czystka etniczna” albo „zbrodnia przeciwko ludzkości”. W ostatnich dwóch rozdziałach książki wyjaśnia, jak różne grupy działaczy politycznych, a nawet naukowców nadużywały terminu „ludobójstwo" do promowania narracji wiktymizacji. Przy tym podkreśla, że celem jego książki nie jest dowiedzenie, że pewne okrucieństwa popełnione przez OUN miały charakter ludobójczy i nie porównuje ich z Holokaustem ani innymi masowymi zbrodniami w celu podniesienia rangi cier- 
pienia jakiejś konkretnej grupy. Autorskie użycie terminu „ludobójstwo”, jakie nam proponuje, zakłada u sprawców intencję likwidacji grupy lub wspólnoty ze względu na jej tożsamość narodową, kulturową albo etniczną zgodnie z zasadą, że rozwój i życie jednego narodu są uwarunkowane śmiercią i zniszczeniem drugiego narodu. $Z$ tego samego powodu wskazuje na niejednoznaczny charakter przemocy dokonanej przez OUN, która była skierowana przeciwko różnego rodzaju wrogom etnicznych i przeciwnikom politycznych, ale nie w takim samym stopniu.

Przyjęcie przez autora takiej właśnie pozycji badawczej sprawia, że na wiele pytań nie udziela on odpowiedzi. Sądzę, że łącznie z zamieszczonymi w recenzowanym studium materiałami posłuży ono historykom, w szczególności ukraińskim, do dalszych badań nad omawianą problematyką. Tym bardziej że jak całkiem słusznie zauważył autor,

ta debata dotyczy nie tylko historii, ale też tożsamości ukraińskiej, która wciąż podlega procesowi kształtowania się. Trudno jest przewidzieć, jak wiele czasu zajmie ten proces i jaki będzie jego wynik [...] Niemniej, ukraińscy intelektualiści i politycy [...] nie muszą się zachowywać, jak gdyby nie mieli żadnej kontroli nad [...] procesem tworzenia nowej tożsamości ukraińskiej. W końcu, nikt poza nimi nie będzie musiał przemyśleć „niewygodnych” aspektów historii Ukrainy powiązanych z Banderą.

Ihor Iljuszyn 
